\section{Pakistani satellites}

PAkistan is close to making a decision on plans for the launch of a pair of direct television broadcast satellites. According to the chairman of Pakistan's Space and Upper Atmosphere Research Commission (SUPARCO), Salim Mehamood, the Parliament will soon have to debate the funding share of the various agencies that will use the two "Paksat" satellites.

Pakistan has been stimulated by Indian successes with its SLV-3 rocket, which Pakistan claims could be used as an intermediate-range ballistic missile, to give more weight to space development. A tenyear plan stressing the need for indigenous launch capacity has been released and earlier this year a new facility for the production of solid fuel was inaugurated. At present, Pakistan's capabilities encompass only the production and launch of sounding rockets from its Sonamiani Beach base near Karachi. Paksat would be launched abroad.

Space development could well be hastened by cooperation with other Islamic countries. Serious efforts are being made towards the creation of an Islamic Space Institute with Bangladesh, Egypt, Saudi Arabia, Indonesia, Iran and Turkey as partners.

R.R.

\section{Collider sites}

OF the 43 sites proposed for the Superconducting Super Collider (SSC), 36 have survived internal screening by the US Department of Energy (DoE), and have been passed on to the National Academies of Sciences and Engineering for more detailed assessment and reduction to a shortlist, to be announced next January (Nature 329, 92; 1987).

The only rejected site with official state backing was New York's proposal to build the SSC partly in Canada. Three New York locations wholly within the United States remain in contention. Bids were also disqualified if they did not fully demonstrate that the site could physically accommodate the SSC layout, had adequate electricity or water supply, would come free of cost, or was environmentally acceptable. Three of the unsuccessful bids were in Texas, but the state still has two official sites and two backed by county governments, as well as an interest in a site in New Mexico.

D.L.

\section{British space lobby}

BRITISH industry is continuing to lobby the government for greater investment in space research. British Aerospace has written to 135 members of parliament and peers of the House of Lords pointing out the benefits to the economy of an expanded space programme. In particular, the need for Britain to at least retain its current position in the European Space Agency is emphasized.

\title{
Britain's genetic manipulation regulations to be extended
}

\section{London}

VOLUNTARY schemes for notification of the deliberate release or industrial use of genetically manipulated organisms in Britain are likely to be replaced by compulsory notification. Any failure to notify the Health and Safety Executive (HSE), whose commission proposed the changes last week, would become a legal offence.

The Health and Safety Commission, which put forward the changes after consultation with its Advisory Committee on Genetic Manipulation, says its main objectives are to ensure the proper risk-assessment of planned release and industrial use of altered organisms, and effective inspection of the establishments concerned.

But the changes are also designed to remove the anomaly that notification of the genetic manipulation of organisms is already compulsory, whereas the employment of the organisms, which may well carry a greater risk, is not. The changes are expected to anticipate the recommendations of the Royal Commission on Environmental Pollution that is due to report on deliberate release experiments within the next few months.

The HSE also hopes to make compulsory two other aspects of genetic manipulation that are currently voluntary. One would make it essential for anyone notifying the HSE of a genetic manipulation experiment to assess the risk of the experiment by a method approved by the HSE. The other would make it compulsory for any establishment that carries out genetic manipulation to set up a safety committee.

Other changes proposed in last week's consultative paper are designed to close two loopholes in existing regulations. No longer would it be possible, in theory, to argue that the direct incorporation (by, for example, microinjection) of foreign DNA into cells is not subject to regulation. And deliberate release from offshore installations (an oil rig, for example) would unambiguously be covered by the new regulations, although strangely they would not apply to ships in territorial waters or aircraft flying over them.

In one respect the new regulations would somewhat lighten the bureaucratic load on British genetic manipulators. Those involved in work that is categorized as low risk will need only to give numbers rather than details of their experiments in the annual retrospective notification they have to file.

Peter Newmark - The UK Department of Trade and Industry is hoping to interest companies in jointly funded experiments to assess the risk of deliberately releasing genetically manipulated plants or microbes. If experiments of sufficient interest to a number of companies can be identified, the department's Biotechnology Unit is prepared to pay half of their cost.

Roy Dietz, head of the unit, anticipates that such experiments will be carried out under contract at independent laboratories, such as those of the Agricultural and Food Research Council or Natural Environment Research Council that already have experience in deliberate release experiments. A major aim of the "Planned Release of Selected and Manipulated Organisms" initiative, he says, is to hasten the evolution of a framework for deliberate release, which is being constructed on a case-by-case basis by the Advisory Group on Genetic Manipulation.

\section{Genentech lose Protropin case}

\section{Washington}

A LEGal dispute between Genentech and Eli Lilly over recombinant human growth hormone has prompted a review by Congress of the Orphan Drug Act, the law intended to give commercial protection to companies making treatments for rare diseases.

Genentech filed a case against the Food and Drug Administration (FDA) in March, after the FDA approved Eli Lilly's form of recombinant human growth hormone, Humatrope, under the Orphan Drug Act (see Nature 326, 231; 1987). Humatrope differs from Protropin by one amino acid, so it was considered a new drug by the FDA. But Humatrope is also used to treat dwarfism, and Genentech claimed that its marketing exclusivity for Protropin was being infringed.

Genentech last week learned that a complex legal strategy to protect Protropin from competition was a failure. Genentech sought to void both its own and Lilly's protection under the Orphan Drug Act, claiming that neither Protropin nor Humatrope was a "new drug", and that neither should be protected by the act. But a US Federal circuit court judge dismissed that argument, upholding the rights of Eli Lilly to market their drug.

Now the legislature is gearing up to clarify the Orphan Drug Act, to be introduced into the House on Tuesday. As Nature goes to press it is unclear whether the amendments will define the term "drug" in the context of the act, or establish a principle of "shared exclusivity", several drug manufacturers enjoying market protection for the same product for slightly different indications.

Carol Ezzell 